\title{
GÁBOR FEKETE (1930-2016) \\ BEGINNING OF HIS CAREER AND YEARS SPENT IN THE NATURAL HISTORY MUSEUM
}

\author{
Norbert BAUER \\ Department of Botany, Hungarian Natural History Museum, \\ H-1087 Budapest, Könyves Kálmán krt.40, Hungary; bauer.norbert@nhmus.hu
}

Bauer, N. (2017): Gábor Fekete (1930-2016). Beginning of his career and years spent in the Natural History Museum. - Studia bot. hung. 48(2): 153-172.

\begin{abstract}
Gábor Fekete, member of the Hungarian Academy of Sciences, passed away in the autumn of 2016, worked at the Department of Botany of the Hungarian Natural History Museum from 1954 to 1977. This paper wakes the first part of Gábor Fekete's career, his decades spent at our department. His research and less known activities as a museologist are summed with the help of our science history documents and reminiscences. Over the demonstration of Gábor Fekete's years at the Museum, the paper gives introspection to the researchers' work atmosphere in that time and to the history of our department from 1950s to 1970s.
\end{abstract}

Key words - ecology, Herbarium Carpato-Pannonicum, museology, science history, vegetation research

\section{INTRODUCTION}

"The most rewarding part of the work of a botanist is the fieldwork, the time of interesting observations. This is a real experience, an uplifting feeling that immensely inspires the researcher. So in return we have to think about their meaning." These were the words, Gábor Fekete (Budapest, 20 April 1930 - Dunakeszi, 29 November 2016, Fig. 1) used to sum up the beauty of existence as a botanist, and the mission of a scientist in 2015. The Professor for many of us, member of the Hungarian Academy of Sciences, passed away last autumn at the end of November. He lived his life according to the above principles.

Gábor Fekete worked for more than two decades from 1954 to 1977 at the Department of Botany of the Hungarian Natural History Museum. This is where he became an internationally recognized ecologist from an entrant botanist. During the years spent at the Department of Botany, in the diverse museological work, besides the experiences of inspiring joint research with good friends, he also suffered from the disappointments and injustices deriving from the political system and human deprivation at that time. Gábor Fekete did not complain about this, but his voluntary quit from the Department of Botany was not a coincidence 
and not a decision without a good reason. He closely followed the work of the Department of Botany the situation and destiny of the Hungarian Natural History Museum up to the end of his life. Our remembrance sums up the beginning of Gábor Fekete's career and the year spent at the Department of Botany based on his own narratives, as well as relying on NHMUS's archive and science history documents. To provide this brief overview, a great help was given for the correct merging of data and circumstances by Gáborné Fekete, born as Etelka Szücs and Tibor Kecskeméti, a fellow student at university and later colleague at the museum.

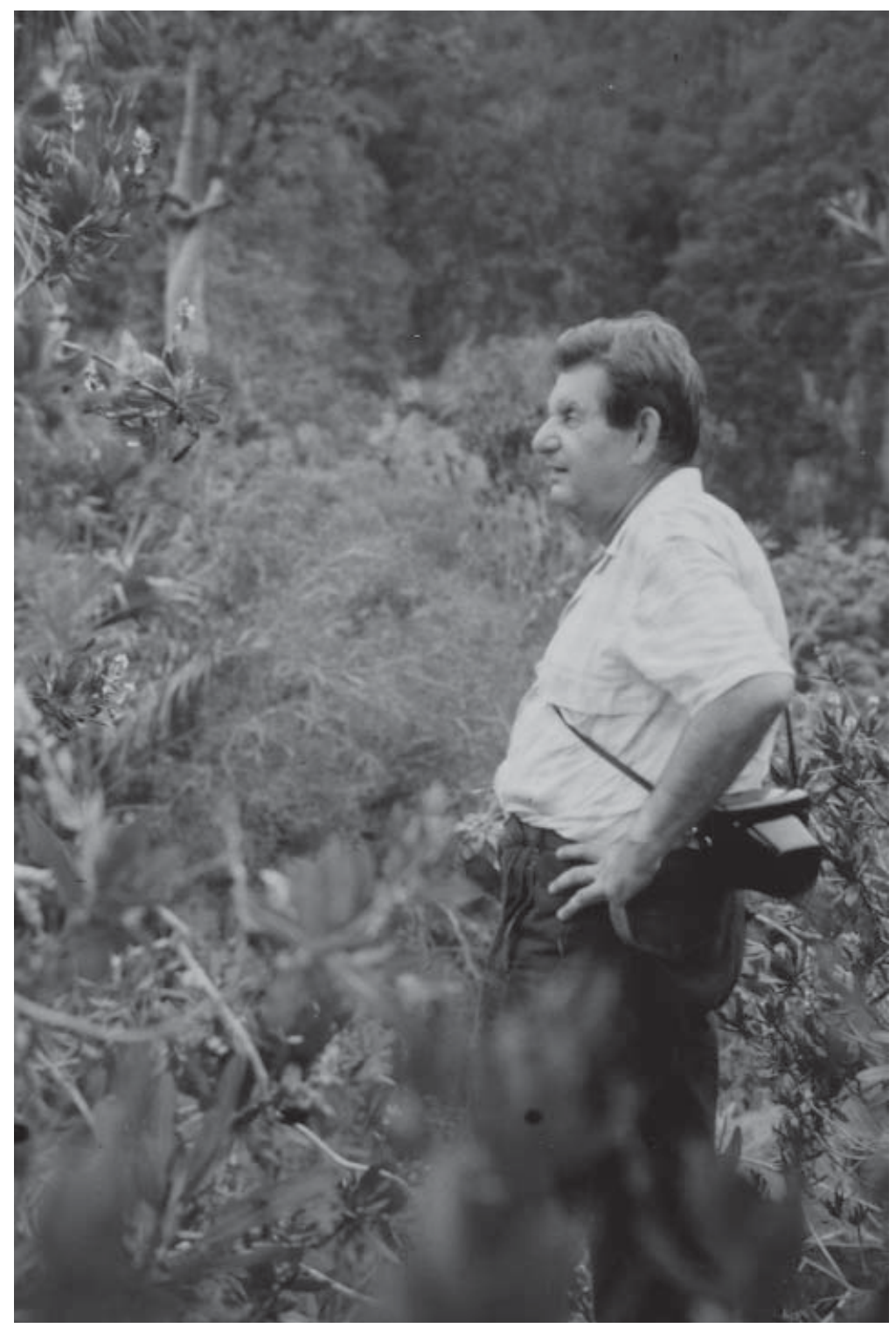

Fig. 1. Gábor Fekete in Cuba, 1988 (photo by Attila Borhidi). 


\section{EDUCATION}

Gábor Fekete was born on April 20, 1930 in Budapest. His mother, Mária Deák (1894-1962) and his father, Miklós Fekete (1875-1965) worked in the post office, living a simple civic life. Gábor was four or five years old when the family moved to Székesfehérvár. Despite their modest financial resources, the parents did their best to provide a good education for their only child. The happy school years were followed by years spent at St. Stephen High School of the Cistercian Order in Székesfehérvár, which was always recalled by Gábor Fekete amongst his most cherished memories. He graduated in 1948. He was admitted to the BiologyChemistry major of the Pázmány Péter University in 1949 (from the second year, 1950, Eötvös Loránd University of Budapest). He always excelled in the special subjects, only received weaker grades in the subjects of ideological education (Ideology, Marxism-Leninism). Initially, he had long-term plans with chemistry, but - according to his classmate and his later wife - due to his excellent teachers, his interest soon turned to biology, especially botany. Taxonomy, plant genetics, plant ecology and palaeobotany were taught by Gábor Andreánszky, plant anatomy and morphology by Árpád Haraszty, moss studies by Ádám Boros, lichens by Ödön Szatala, mycology by József Bánhegyi, soil studies and soil biology by Róbert Ballenegger. The fact that he could study phytosociology from Bálint Zólyomi had a great impact on his later career, and his chosen fields of expertise. In special colleges he studied microclimatology from Tamás Révész, while the knowledge of the woody plants of Southeast Europe was taught by Zoltán Kárpáti.

Gábor Andreánszky, the globetrotter, head of department, had the greatest influence on him, and during their discussions, he could get acquainted with the current issues and opinions of phytogeography and vegetation history. Besides being a legendary teacher with a good didactic sense, Andreánszky considered common fieldwork and thorough knowledge of vegetation and plant species highly important. He took his disciples regularly to the Buda Hills. At that time Andreánszky already did not organize great, oversea journeys (South Europe, North Africa) characterising the earlier years of his career, but in the summer of 1952, the professor managed to arrange his biology major students (along with students from Szeged and Debrecen) to go on a trip all across Hungary. During this three-week-long tour, the youngsters could explore the country's vegetation from the hills of Sopron and Pécs to several parts of the Great Hungarian Plain. The Sas Hill and the Ördög-orom in the Buda Mts were one of the regular targets of the more frequent, "Andreánszky excursions" around Budapest much anticipated by his students. At those times, in the nearby Ördög-orom Inn, Andreánszky at his own expense usually had a small barrel of beer tapped, and while the refreshments were consumed by the students, they did not fail to discuss professional issues either. The professor soon realized that besides having 
a solid knowledge, the young Gábor Fekete already had a vision of botanical issues although he was only a university student. He paid particular attention to his most talented disciples, and often received them in his own university study. The students who earned the honour, including Gábor Fekete, Magda Komlódi and a few others in the early 1950s, had a place provided at the long table in the outer room, where they could read professional literature. Being an "outerroom student" meant that they had entered the antechamber of science. Gábor Andreánszky was removed from the university due to political issues in 1953 (see HORÁNSZKY 1996), he got a position as a museologist in the Natural History Museum. Rezső Soó was appointed as the new head of department.

Gábor Fekete's devotion and diligence were also respected by his classmates at university. According to Tibor Kecskeméti, Gábor summarized the distribution data of the plant species in the library of the Geographical Institute of the University in his free time, on less busy days when others tried to relax.

In the third year, biology and chemistry major students could decide whether to pursue their studies for a university degree as a teacher or a specialist. Gábor Fekete and his friend, Magda Komlódi, and among others, Klára Verseghy and Júlia Lacza chose the latter. They graduated as chartered botanists in 1954 .

Gábor Fekete was strongly attached to his parents and his parents' home. He went home from the University every few weeks and from his third year at the university on, setting out from Székesfehérvár, he toured the Velence Mts on a regular basis. As a result of this field research, his first publication about the discovery of the Chlorocyperus glaber in Hungary (FEKETE 1954, Fig. 2) was released, which was followed by his diploma work in 1954, then a scientific article on the vegetation of the Velence Mountains (Fekete 1955).

\section{THE YEARS IN THE NATURAL HISTORY MUSEUM}

As early as in the fourth year of the university, Gábor Fekete knew that he was going to work at the Department of Botany of Natural History Museum after the university. Several friends and acquaintances were awaiting him there. At that time, Bálint Zólyomi was the head of the Department of Botany, while Gábor Andreánszky continued his research as a museologist, and at that time he was mostly involved the field of palaeobotany. A friend of his, Pál Jakucs also worked there. They were looking forward to the arrival of the talented, young botanist indeed, which is also evidenced by the fact that the 1953 annual report of the Department of Botany included the newly recruited young from 1954: Gábor Fekete. At the same time, Klára Verseghy and Júlia Lacza also joined the department. In the first years, Gábor Fekete shared a room with Andreánszky, so the master and disciple continued their discourse on phytogeographical issues on a daily basis. 


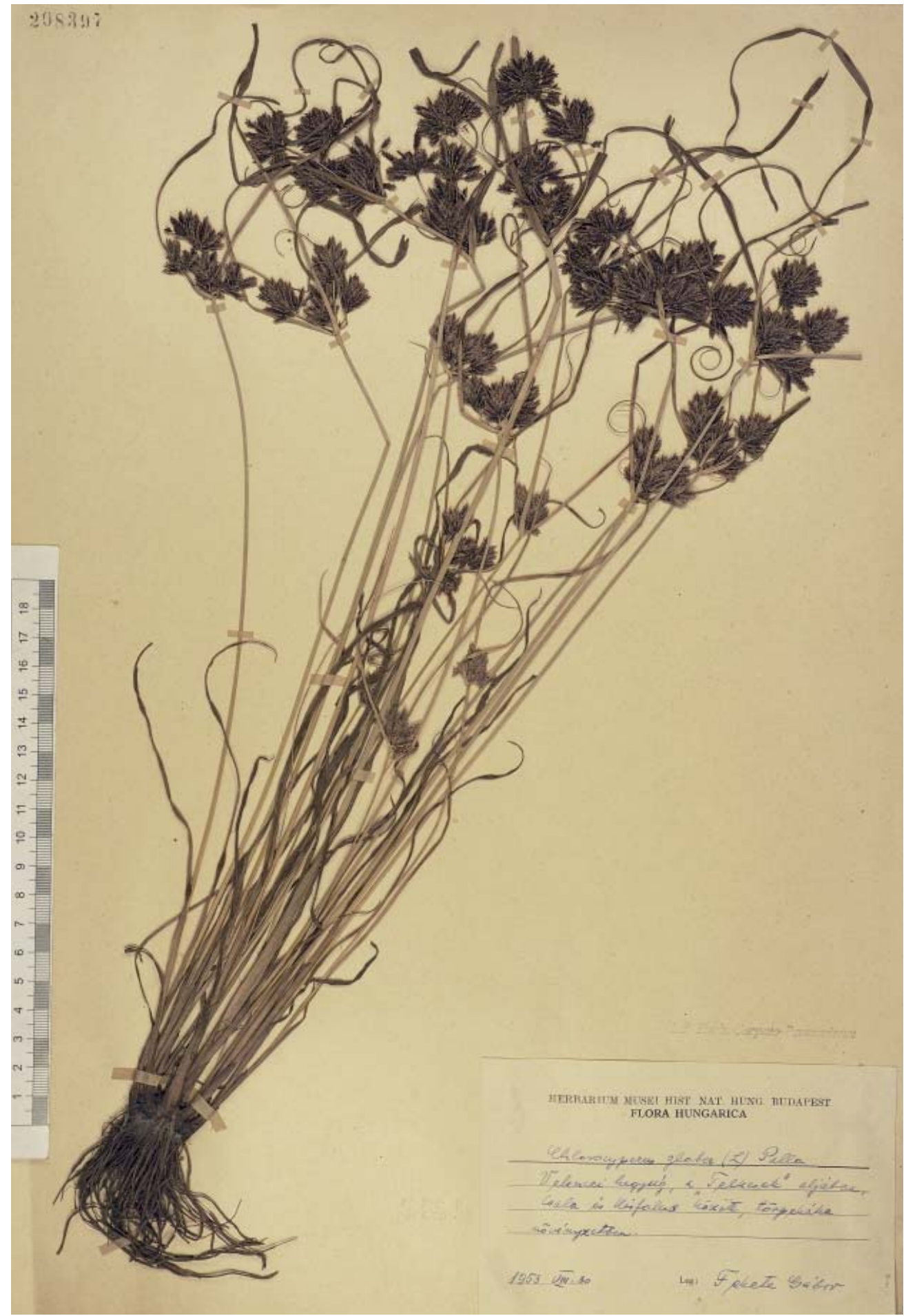

Fig. 2. Specimen of Chlorocyperus glaber collected in the Velence Mts by Gábor Fekete. 
He sought to meet all three functions of museum work all along. He was involved tasks related to collecting work, participated in the knowledge share, in accordance with the role of museums in society. However, there is no doubt that he was most keen on dealing with research projects.

\section{Gábor Fekete as a museologist}

His collecting work in the Department of Botany for more than two decades, beyond the processing of materials collected on his own research topics, was very diverse. In terms of herbal affairs, he had a permanent job of arranging loans and international exchanges (see Annual Work Reports of the Department of Botany, 82/1962-N). He was in charge of herbarium-related preparatory works, the scheduling and arrangement tasks related to "Flora Carpato-Pannonica" collection. He reviewed private collections several times, as well as collections lost or stored under inappropriate conditions in other institutions. According to one of the surviving reports $(72 / 1957-\mathrm{Nt})$, in 1957 , he was appointed to review the Feichtinger Herbarium, which was stored in the technical rooms of the Pedagogical Institute in Esztergom (in two glass cabinets, 84 bundles, about 10,000 sheets). He established that "it would be more appropriate to store the collection at the Department of Botany", but because of the lack of space the transfer of the entire material was unrealistic, he considered a good idea to sort the precious materials, or least to "periodically check the collection by a delegated researcher of the Department of Botany". (Unfortunately, there is no information available on the fate of this part of the Feichtinger Collection is unknown today.) He contributed, inter alia, to the saving of private collections of József Budai, Géza Zemplén (FeKETE 1962a), and the processing of the herbariums (eliminating duplications, gluing, arrangement) of Ádám Boros, Zoltán Kárpáti, Antal Pénzes, and József Papp. From 1969 to 1970, he participated in the selection and sorting of the garden and botanical garden materials during the development of the collections of culture plants. In 1975 the relocation of the university's floral plant collection was a huge challenge. He has made a significant contribution to the compilation of the paper completed in 1971 titled "The history of the 100-year-old Department of Botany" (BoHus et al. 1971). The chapter dealing with the history of Herbarium Carpato-Pannonicum was published a few years later as an independent professional article (FEKETE and Kováts 1974).

There was no separate funding dedicated to finance field collections. Most of the museologists went to field trips at their own expense. They usually took a train for these backpack-and-boot tours, often accompanied by acquaintances and relatives (e.g. in Bakony, at Ajka, at Gábor Bohus's relatives). Sometimes, in more fortunate cases, they could also collect at trips related to exhibitions or be 
under the projects related to their academic research themes. In addition to the actual financial subsidy, sometimes they could also take advantage of the "academic touring taxies" (35/1960, FEKETE 2002).

From the end of the 1950s the need to present the scientific results to society by the museums became increasingly pronounced. The maintainer expected from the institutions the communication of the areas considered significant in terms of the people's economic issues. Taking advantage of this demand, it was also possible to offer a glimpse into ecological and nature conservational aspects as well Gábor Fekete, Pál Jakucs, Tamás Pócs and Bálint Zólyomi through the results of their geobotanical researches, were amongst the first to present plant associations at their exhibitions in Hungary, and they also spoke about the fundamental importance of plant geographic and farmland conditions in the development of our countryside. During the time of "saving schemes" (circa 1960, see 38/960) exhibitions were maintained and renewed by the staff of the Department of Botany, including cleaning tasks, technical improvements to the replacement of damaged plant specimens. Museologists were actively involved in the processes from the collection of exhibition material through screenwriting to showcase arrangements, often taking part in the cleaning and restoration of showcases, too. In order to serve the exhibitions and to replace the defective materials at the Department of Botany, there was a "basic collection for exhibitions" at the time, and museologists were expected to develop it, and the researchers were informed about the species to be collected through the list displayed on the corridor wall. The collections of material related to exhibitions often realised at cheerful common excursions. The co-operation of the colleagues of the Department of Botany yielded the first permanent exhibition specifically focusing on botany in Hungary in the halls and staircase of the building of the department at "Vajdahunyadvár" in the City Park of Budapest (JAKUCs 1956). In addition to the plant exhibitions at the Department, the botanical aspects of the natural history exhibitions built on external locations were often implemented by the museologists of the Department of Botany. Gábor Fekete also guided school groups at the exhibitions of the Department of Botany, he developed museum quizzes if he had to, while at other times he was proofreading scripts in order to safeguard the quality of the material displayed at natural history exhibitions arranged in the country $(220 / 1963-\mathrm{N})$. In 1954 he made the scenarios of the botanical part of the exhibitions to be realised in Kecskemét, then in 1955 in Miskolc and Keszthely, and in 1956 he compiled the professional material for the wine-growing sections of the Badacsony exhibition. He had a particularly important role in the implementation of the first Bakony natural history exhibition of the Veszprém County Museum (1959), but in 1971 he also had important tasks related to the 200-year-old university botanical garden exhibition as well as to the Hanság exhibition in 1977. 
Gábor Fekete took part in the popular-science and educational tasks of the museum by giving lectures (e.g. in Kossuth Klub in Budapest and TIT in Székesfehérvár), holding classes (e.g. at the botanical student classes of Uránia science-educational store), by writing popular-science articles (FEKETE 1958a, $1958 b, 1961 a, 1962 b, 1964 b$ ) and other professional materials (e.g. FEKETE $1958 c$ ). At the request of the Science Educational Society, he undertook the professional guidance in the Buda Mts (usually departing from the Újlaki Church) and was involved in the scientific training meant for biology supervisor teachers.

\section{Gábor Fekete as a researcher}

From the very beginning, Gábor Fekete's scientific interest was focused on getting to know the vegetation and understanding its history and function. His territorial attachment to the Bakony Region developed as a young, entrant botanist (cf. FEKETE 2002). During the weekends visit to home, he often visited the mountains of the Eastern Bakony west of Székesfehérvár rising in "inviting proximity". In parallel with the Bakony hikes, from the second half of the 1950s, as a member of the "Bükk brigade", including Jakucs and Zólyomi, he studied the regional differences of the Pubescent oak forests and other forest associations. Quite certainly, his increased interest in Pubescent oak forests and forests on rocky surfaces, and a number of special areas of expertise that he researched throughout his career (e.g. forest-steppe question, succession researches) are rooted in these excursions.

The research work in the museum was carried out at the time under the supervision of the Department of Biology of the Hungarian Academy of Sciences. This meant, on the one hand, that annual work plans and work reports on scientific work had to be sent to the Academy for approval. In the 1950s and 1960s, the underlying reason for academic support of geobotanical research was the assumption that a better understanding of the relationship between plant associations and the environment could provide guidelines for forestry farming plans, for example. In the 1950s and 1960s a strong phytogeography team was working in the Department of Botany of the Natural History Museum. The group was led by Bálint Zólyomi, the museologist colleagues included Pál Jakucs, Gábor Fekete, Tamás Pócs (later as an external member of team), Zoltán Baráth and Gábor Bohus. They were involved in complex geobotanical projects, exploring plant associations and their spatial, temporal changes and their rules. Their major projects included the launching of the Vegetation of Hungarian Landscape series and the completion of other vegetation monographs (Fig. 3). Several great works of the Hungarian vegetation research are due to the decades of hard work of this research group (e.g. Pócs et al. 1958, JA KUCS 1961, Fe KETE 1965). 


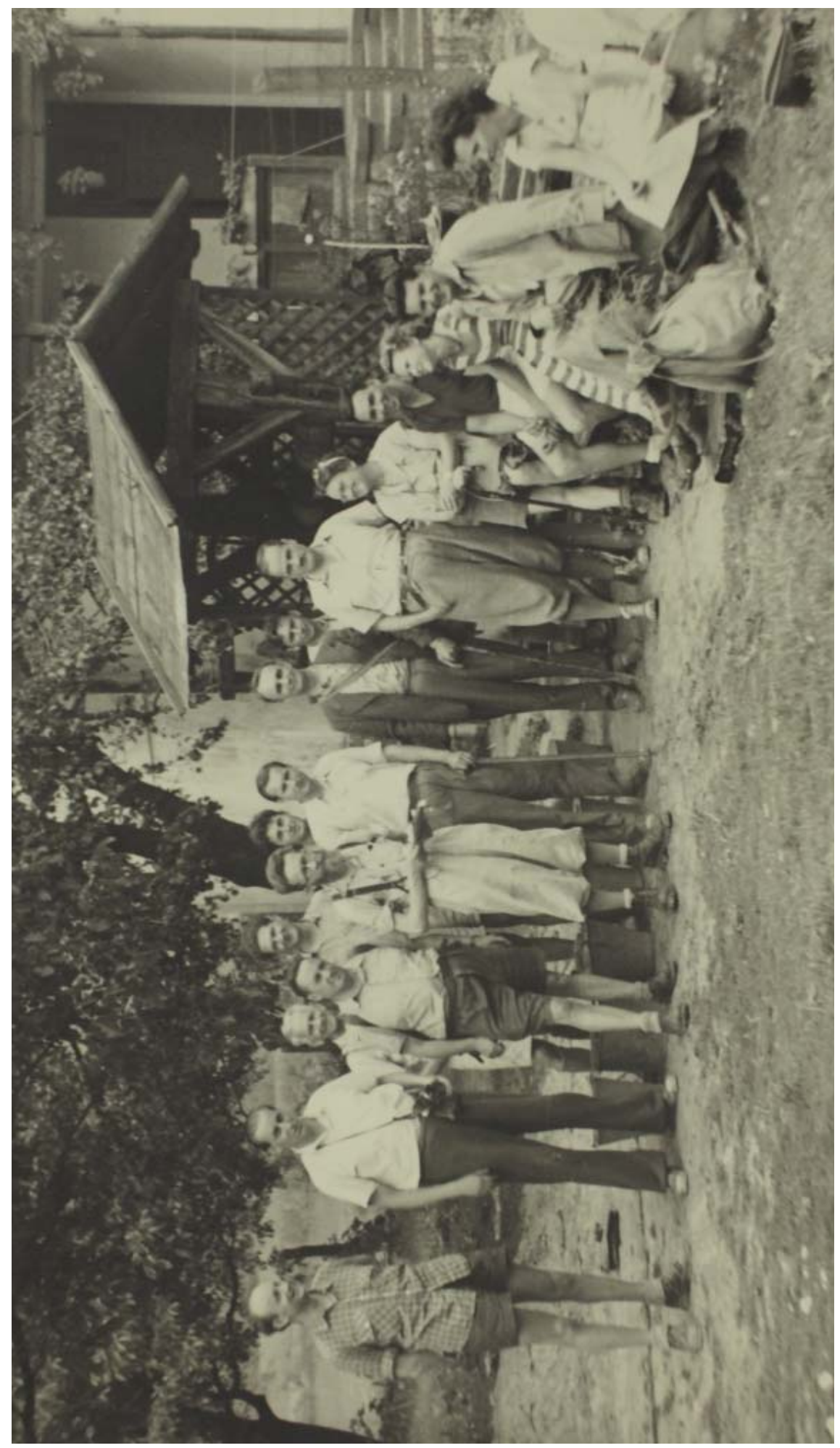

莺起

ㄱ. 을

चี

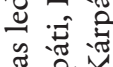

3 는

诲谣

है क

点

की हो

๙ิ

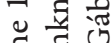

$\mp \Xi$

जी की नै

范落

는

艺 窎

ड़

氙

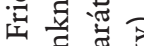

4.

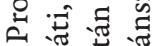

岁

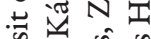

罂然

吾芹

แ N

กิ हี

ปี :

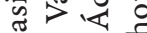

造造

西

I

ธิ

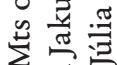

चี

th

要 =

$>$ 年

क क त

‡

$\Xi$ 華

is

舟

휴

पे

要通

$\exists$

总商

理

$\dot{m}$

․․․ 工

的 
In the first decade spent at the museum, Gábor Fekete focused heavily on the vegetation of the Bakony Region and its phytogeographical features. In particular, he studied the beech zone of the High Bakony, (centred in Bakonybél, Gyertyánkút) and the zone covered with hornbeam-oak forests at the border of Eastern-Bakony and High Bakony (the area of Gézaháza). By processing and elaborating this topic, he obtained a university doctorate in 1959. Great attention was given to the publication of the Stipa bromoides population from the High Bakony (FEKETE 1959b).

The Department of Botany was invited to participate in the research project “The Natural Scape of Bakony” by István Éri, director general of the Bakony Museum. Following a discussion with his staff, Bálint Zólyomi responded in a letter that he would delegate Gábor Fekete, Ferenc Radics, Sándor Tóth, László Vajda and Klára Verseghy to represent their own respective fields of expertise (86/1962-N). Thereby, Gábor Fekete as the founding participant of the regional landscape research program launched and co-ordinated by Jenő Papp could carry out his research in the area with some backing (BAUER and KeNYERES 2002). He restarted the research with renewed enthusiasm and motivation, his dream being the monographic processing of the vegetation of the Bakony. According to his annual work schedule, Gábor Fekete aimed to investigate new plant association groups each year. He studied steppe slopes, hay meadows and willow scrubs, but mostly focused on the processing of forest associations. His papers on the mixed forests of slopes and screes of the Bakony (FEKETE and JÁRAI-KOMLóDi 1962), ravine forests (FEKETE 1963a, 1963b) and xerothermic oak woods (FEKETE 1966) were published one after another. The decade-long Bakony research was completed with the modern phytogeographical evaluations of the landscape (FeKete 1964a, FeKeTE and Zólyomi 1966). The most important result is the recognition of the zonal Pubescent oak forests of the Balaton Uplands.

As a comparative basis, it was a favourable circumstance that, in parallel with the research in the Bakony Region, he could have been involved in the coenological and mapping works of the Bükk Mountains. With his friend, Pál Jakucs (Fig. 4), they co-authored several valuable papers on their favourite joint research field, the xerothermic oak forests, and the shrub-forests, (e.g. JAKUCS and FeKeTE 1957, FeKeTE and JAKUCS 1968).

Gábor Fekete and the young geobotanists of the Department of Biology were absolutely aware of the fact that the vegetation types they studied cannot be appropriately evaluated without understanding their biogeographical relationships. That is why they tried to get acquainted with the associations described in the surrounding countries, and to make exploratory field trips in areas not studied before. As a first step of gaining permission for foreign study tours the head of the program had to submit a draft cultural program (and the cultural agreement between countries) $(110 / 1962)$. In these submissions, it was necessary to justify what countries (mainly 
socialist countries) a researcher concerned wanted to travel to and for what professional purpose. In the 1950 s, botanical study trips were mostly carried out at the researchers' own expense $(1 / 1958,67 / 1958,87 / 1959)$. This is how Gábor Fekete got to Romania in 1956, where in six weeks from Cluj-Napoca (Kolozsvár), through Iaşi and Bucharest he reached Dobrogea and the Lower Danube (Al-Duna) region (see JAKUCS et al. 1959). Also in 1956, a smaller, two-week Czechoslovakian tour, particularly the parts of the Tornai Karst beyond the border had a great impact on him. In 1957, he and Jakucs, again at their own expense, (see JAKUCs 2000) went to study the vegetation of Yugoslavia, with special attention to oak forests on karstic areas (FEKETE and JAKUCS 1958). Then they visited the research sites of the country and met Slovenian, Croatian and Serbian colleagues. Researchers have also submitted their planned program to the academy to gain support for their collection and study trips abroad. It was really difficult for Gábor Fekete to get funding for his study-trip requests by the Biological Group of the Hungarian Academy of Sciences, and his request was rejected several times. Zólyomi, however, always supported his applications (98/1962-N) despite his long illnesses. In 1960, under the "Cultural Exchange Program", with the support of the Academy (35/1960), he could finally spend four weeks in Romania in order to pursue comparative and phytogeography study of calcareous, Hungarian and Turkey oak forests. In 1961, he could spend as many as 51 days in Bulgaria and Romania, funded by the Ministry of Culture (6/1962-N). In the field records he left to the Museum you can easily track the exact route and nature of this study trip. His notes are not dominated by floristic records, wherever he had enough time he documented the interesting forest stocks with phytocoenological recordings. In the Soviet Union, he wanted to study the vegetation belts from the boreal forests around Leningrad, and the mixed forests around Moscow, through the forest steppe near Kremencsug, to the steppes in Voronyez region and the colchic forests at the northern foot of the Caucasus (98/1962-N). In the summer of 1967 (from 12 July to 8 August), Gábor Fekete's great dream of studying the steppe zone of Eastern Europe was finally realized. According to his field records, he travelled with a military car, or with academy Volga, sleeping cars of trains, and a plane, stayed at better and worse accommodation, alternating between tense and cheerful days, and eventually gained a lot of such experience on guided tours that later became decisive in his phytogeography approach. It is also clear from some of the coenological samples made on this trip that he was primarily occupied with the understanding of the connections among the forest steppes, forest ecotones and saline grasslands of the Carpathian Basin. He returned to Czechoslovakia (1964) and Bulgaria (1973) during his geobotanical study trips, too. The foreign study tours yielded many valuable scientific results. Gábor Fekete described the black pine forests of Domogled (FEKETE 1959a), the Southern Carpathian rocky woods of walnut and Turkish hazel (FEKETE 1967), yet they played the most important role in the 
appreciation of Hungarian oak forests, and the understanding of their relationship with the deciduous oak forests of the Balkans and Eastern Europe. He went back to the Soviet Union in 1971, and during this trip he could refine his expertise in plant physiology, acquired laboratory skills and learned methods suitable for instrumental field testing of vegetation. He travelled to the Caucasus in the early 1980 s with his family as part of a package holiday organized by IBUSZ tour operator. However, he did not have the opportunity to research; when he unsuspectedly went into a forest, he was immediately stopped and was instructed to return to their accommodation.

During the vegetation research of the Gödöllö Hills, besides understanding some coenological and phytogeographical aspects, he developed increasing interest in ecological issues. An outstanding achievement of his research in the Gödöllö Hills is the recognition of remnants of the cold continental forest steppe in Hungary (FEKETE 1961b). Gábor Fekete submitted application for candidate's degree in $1963(27 / 1963)$ and referring to his results, Zólyomi recommended Gábor Fekete to the Scientific Qualification Committee in the same year to candidate's degree (227/1963-N). As a result of his vegetation monograph (FEKETE 1965 ) and dissertation titled "Studies on forest vegetation in the Gödöllo" Hills" in 1966 he became a holder of a candidate's degree.

His coenological and phytogeographical interest of the first decade of the Department of Botany gradually shifted towards ecology from the mid-1960s. Initially, his interest was expanded with physiognomic and microclimate studies of plant associations. Later, understanding of the operation, and inter-specific interactions became the focus of his interest. A decisive momentum in this change of subject, causing a bitter mouth taste to Gábor Fekete (and distancing him from coenology) occurred after he had shown to Rezső Soó the unprocessed, tabular data collected in beech forests of the Bakony Region in 1964 (approximately 100 handwritten coenological relevés). Surely this, and then István Isépy's research in the Vértes Mts, convinced Rezső Soó of the autonomy of the beech forests of the Transdanubian Mountains and this was the basis for the Laureolae-Fagetum association (Soó 1971, 1973), published by Soó - without a detailed study. Though Gábor Fekete's plans included the complex, synthetic processing of the beech forests of the Bakony Mts, this incident discouraged him to realize this plan and deal with coenology altogether. In the early 1970s, he intended to go for the great project of the phytocoenological monographic processing of the Balkan zonal oak forests, but finally he failed to realize it either. Due to the "cold war atmosphere prevailing in Hungarian coenology" (mainly the Zólyomi-Soó conflict), both him and Attila Borhidi were worried, who at that time worked at Soós department (BORHIDI 2000).

Gábor Fekete tried to find a new, perspective field of research. He did not go away from vegetation research, but his focus shifted to the understanding of the operation and to the dynamic issues. In his choice of topic, he emphasized 
experimental ecological studies on plant associations. Although he used to excel at mathematics and related sciences at university, he soon realized that his proficiency at mathematics is not enough to solve ecological issues. According to his wife, he was already a renowned and acknowledged scientist, still he took private

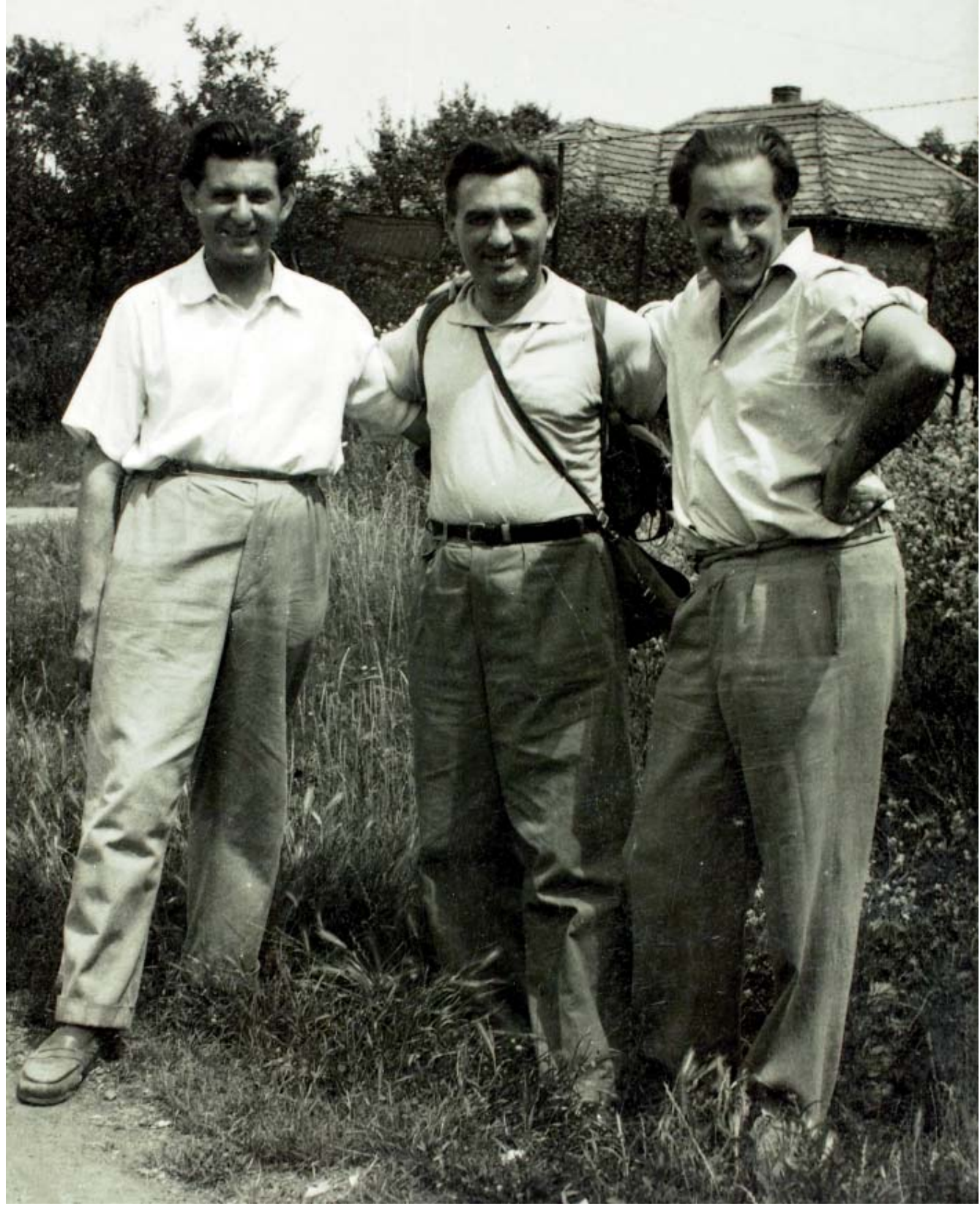

Fig. 4. Gábor Fekete, Ján Michalko and Pál Jakucs on the Remete Hill (Buda Mts) in the 1960s. 
tutoring from as a mathematics teacher to master the high mathematics and statistics at an appropriate level. He did not abandon his favourite Pubescent oak forests even when, following the order of the superiors, he had to deal with production biology (as well) in the 1960s. In the middle of the 1960s he and István Précsényi studied the structural differences between the Pubescent oak forests of the Bakony and Bükk Mountains (PrÉCsÉnYI et al. 1967). He also set up complex ecological experiments on them. He carried out quantitative ecological examinations in the calcareous oak forests of the Remete hill at the Buda Mts. He shed light on the relationship between plant species and soil parameters (SzUJKÓ-LACZA and FEKETE 1971), he studied the undergrowth types and interspecific associations of calcareous oak forests (FEKETE and SzÖCs 1974), and he investigated the correlation between relative illumination and spatial distribution of forest species (FEKETE 1974b). Between 1972 and 1975 he dealt with experimental production-ecological examination of populations, with special emphasis on the ecological factors controlling the occurrence of Polygonatum odoratum (FEKETE 1975a), the $\mathrm{CO}_{2}$ gradients of association atmosphere (FEKETE 1973), the development cycles of OrnoQuercetum species, phenometrics and allelopathic effects. In addition to field observations, he carried out eco-physiological tests as well. He revealed the ecotypes of Polygonatum odoratum characterized by three different light-photosynthesis curves (FEKETE 1974a, 1975b). In 1975 he received the degree of the doctor of biological sciences with his dissertation titled "Interspecific connections, correlations and the analysis of the ecological niche in oakwood species" (FEKETE 1974c, 1975c).

His scientific work, along with these main lines, was very varied. In the early 1970s he participated in some specific floral and coenological tasks at the Síkfókút MAB sampling area, and later he carried on coenological, phenological and association succession tests in the Hortobágy National Park. He was involved in the flora surveying project coordinated by the Department of Botany, he supported Hungarian nature protection efforts from the beginning with his knowledge and opinions. In 1976 he made a compilation for the National Nature Protection Authorities $(\mathrm{OTvH})$ for areas of the Velence Mountains worthy of protection.

From the beginning of the 1970s Gábor Fekete also taught at the Departments of Plant Biology and Phytogeography of the Faculty of Natural Sciences of Eötvös Loránd University. From 1973 he was the editor of Studia botanica hungarica, the periodic botanical journal of the Hungarian Natural History Museum, and reviewer countless of scientific articles.

On the circumstance of work carried on in the Department of Botany

According to the memoires of Gábor Fekete available and the surviving documents, it is clear that his years spent in the Department of Botany were a 
difficult period, full of struggle for the individual. Nowadays, it might not be possible to explore every momentum of the struggle of Gábor Fekete and his coworkers, because unfortunately many documents are incomplete or disappeared from our Science History Collection. Probably, the more embarrassing, more delicate issues could have been filed as "Confidential" and those documents seem to have survived in fragments.

Some of the difficulties were typical of the era, and some of it were caused by human flaws. Things that would be considered as absurd in the present, in the Orwell-style reality of the fifties and sixties were a natural part of everyday life. The researchers of the Department of Botany had to attend centralized museum ideological courses, and in their annual reports had to report on the number of hours/cases dedicated to them. The younger generation cannot even imagine the difficulties of professional communication and visual documentation (e.g. "the long-distance phone calls" could be made only by means of a separate written request (e.g. 181/1961-N); prior to the development of "a Kodak colour stripe of film" an official statement had to be made that they include "exclusively professional (botanical and ethnographic) exposures." (179/1961-N).

The first few years at the Department of Botany, thanks to colleagues, was an inspirational medium and a solid professional background for Gábor Fekete. He was working under Zólyomi's guidance, but despite the circumstances, there was a basically pleasant atmosphere in the Department of Botany. The regular discussion of joint research and experience brought countless professional results.

The early 1960s brought several decisive changes in Gábor Fekete's personal life. He could hardly get over the loss of his mother in 1962, and he had been on sick leave for a long time. In 1963, his fate turned to the better. At a university reunion he met one of his one-time chemistry-major fellow associate, Etelka Szücs (1930-), and they got married the same year. His wife was also a true friend, a spiritual companion. In 1971 they had a child, Zoltán Fekete.

The geobotanical team of the Department of Botany was slowly degraded in the 1960s. Tamás Pócs was appointed for the College of Pedagogy in Eger in August 1962. In 1965 Jakucs was elected as his deputy by Zólyomi, while Gábor Fekete became a senior research fellow (66/1965-N/2, 66/1965-N/3). With these steps, Zólyomi wanted to secure the future of the Department of Botany for the time after his planned departure. In the spring of 1966, the Ministry of Culture agreed to relocate Bálint Zólyomi to Vácrátót, and was appointed the head of the Botanical Research Institute of the Hungarian Academy of Sciences. Soon after his departure his deputy, Pál Jakucs, also left the Department of Botany. The appointment of a new head of department for the Department of Botany must have played a role in this. After the handover procedure, on May 30, 1966, Júlia Szujkóné Lacza was appointed as head of department instead of Jakucs, who was 
proposed by Zólyomi (1966/201-N). Although the decision was professionally incomprehensible, it was not surprising, bearing in mind the political circumstances at the time. Her good relationships at the district party committees, in spite of her professional qualifications, proved to be stronger than the scientific achievements and international acclaim of other museologists of the department. Due to Gábor Fekete's civic ancestry, he was considered as working class alien, he could not be a leader. Mrs. Szujkó was not attacked by the staff of the Department of Botany, but they could not attack her as leaders appointed on a political basis were "the masters of life and death." The tragic situation was mitigated by the fact that she was aware of her shortcomings, "she kept the code of the street" and initially did not attack the more talented and professionally successful colleagues (Kecskeméti ex verbis). At that time, it was well-known that she had relied heavily on Gábor Fekete in writing articles, and in 1969 he had already got a position as deputy head of department. According to the memoirs, they were neither friends nor enemies, and they talked to each other mainly about professional things. Following the degree of the doctor of biological sciences by Gábor Fekete in 1975 their relationship deteriorated considerably. For Szujkóné, it was certainly more and more embarrassing to cope with the professional advancement of his deputy. According to Gábor Fekete's work reports, in 1976 and 1977, it was more and more difficult for him to bear the countless administrative tasks assigned to him by the head of department, "arrangements related to craftsmen and mechanics", carrying out "caretaking tasks" related to procurements, and "the supervision of the heater". According to the recollections by his wife and his colleagues, he sometimes had to carry out receptionist duties. In 1976-77, he was still involved in the preparations and planning of moving the Department of Botany from Vajdahunyadvár to the Könyves Kálmán Circuit, which also involved a lot of tasks keeping him away from his research. Getting over these issues was a serious psychological challenge, but luckily, his wife and friends helped him a lot. Although he was strongly attached to the Department of Botany, he was already considering a possible change of jobs. By the invitation of Attila Borhidi he went to work at the Botanical Research Institute of Vácrátót in 1978. Here, he found a more inspirational environment, where he could once again devote all his energy to research. Due to this brave decision, Gábor Fekete's new and thought-provoking thinking provided solid fundaments for the development of an ecological school over the coming decades.

Acknowledgements - I could not have ventured to compile this memoir had I not been in close contact with Gábor Fekete in the past decade. In addition to our regular conversations, his wife, Etelka Szücs, Mrs. Gáborné Fekete, and his fellow student at university and later colleague at the museum Tibor Kecskeméti provided me great help in recalling the part of his life-story related to 
the Department of Botany. I received a lot of help from my colleagues Réka Sebestyén and Gábor Papp in finding the relevant library and historical documents, so let me express my gratitude to them for their work hereby.

Összefoglaló: A 2016 őszén elhunyt Fekete Gábor akadémikus 1954-től 1977-ig a Magyar Természettudományi Múzeum Növénytárában dolgozott. Jelen dolgozatban felidézzük pályájának első felét, intézményünkben eltöltött évtizedeit. Tudománytörténeti dokumentumok és visszaemlékezések segítségével bemutatjuk a herbáriumhoz és a kiállításokhoz füződő - a közvélemény számára alig ismert - muzeológusi tevékenységét, valamint az itt folytatott kutatásait. Fekete Gábor múzeumi éveinek felidézése mellett a dolgozat betekintést nyújt a kortárs kutatók munkahelyi körülményeibe, valamint a Növénytár 1950-es és 1970-es évek közötti történetébe.

Jelen megemlékezés magyar nyelvü verziója az Annales Musei Historico-Naturalis Hungarici folyóirat 109. évfolyamában lesz olvasható.

\section{REFERENCES}

Bauer, N. and Kenyeres, Z. (eds) (2002): 40 éves a Bakony Természeti Képe program - Tények, képek, emlékek. [40-year of the landscape research program of the Bakony Region - Facts, pictures, reminiscences]. - Bakonyi Természettudományi Múzeum, Zirc, 215 pp.

Bohus, G., Fekete, G., Szuj Kó-Lacza, J. and Ujhelyi, J. (1971): A 100 éves Növénytár története. [History of the 100-year old Department of Botany]. - manuscript, Természettudományi Múzeum, Budapest, 99 pp.

Borhidi, A. (2000): Köszöntö. [Inaugural.] - In: VirÁGH, K. and KUN, A. (eds): Vegetáció és dinamizmus. A 70 éves Fekete Gábort köszöntik tanitványai, barátai és munkatársai. [Vegetation and dynamism. 70-year old Gábor Fekete is greeted by his disciples, friends and colleagues]. - MTA ÖBKI, Vácrátót, pp. 7-8.

Fekete, G. (1954): A Chlorocyperus glaber (L.) Palla Magyarországon. (Chlorocyperus glaber (L.) Palla in Ungarn). - Bot. Közlem. 45 (3-4): 253.

Fekete, G. (1955): Die Vegetation des Velenceer Gebirges. - Annls hist.-nat. Mus. natn. Hung., nov. ser. 7: 343-362.

Fekete, G. (1958a): Örökzöld Dalmácia. [Evergreen Dalmatia]. - Élövilág 3(2): 3-9.

FEKETE, G. (1958b): A szárazságot türő növények. [Drought tolerant plant species]. - Élet és Tudomány 13(27): 840-842.

FeKete, G. (1958c): A növények gyüjtése és preparálása. [Collection and preparation of plants]. manuscript, Uránia-bolt, Budapest, 34 pp.

Fekete, G. (1959a): Angaben zur Zönologie der moesischen Schwarzföhrenwälder. - Acta Bot. Acad. Sci. Hung. 5(3-4): 327-347.

Fekete, G. (1959b): Stipa bromoides (L.) Dörfl., eine neuentdeckte Pflanze in Ungarn. - Acta Bot. Acad. Sci. Hung. 5(3-4): 349-356.

Fekete, G. (1961a): Botanika és erdötipológia. [Botany and forest tipology]. - Term.tud. Közl. 92(5): 206-208.

FEKETE, G. (1961b): Les groupements forestiers à arbres feuillus des forêts steppes fraiches-continentales en Hongrie. - Acta Bot. Acad. Sci. Hung. 7(3-4): 229-233.

FeKete, G. (1962a): Jelentés a miskolci Muzeumban elhelyezett Budai József-féle növénygyüjtemény szemrevételezéséről. [Report about plant collection of József Budai placed in Muzeum of Miskolc]. - manuscript, Budapest, 1960.08.29. MTM Irattár, 1 p.

Fekete, G. (1962b): Növényföldrajzi kutatóúton Bulgáriában. [Plant geographic research tour in Bulgaria ]. - Élövilág 7(6): 3-10. 
Fekete, G. (1963a): Die Schluchtwälder des Bakony-Gebirges. Die Phytozönosen des Bakony-Gebirges II. - Annls hist.-nat. Mus. natn. Hung. 55: 215-231.

Fekete, G. (1963b): Verbreitungspunktkarten der Pflanzenarten des Bakony-Gebirges I. Charakterarten der Schluchtwälder. - Fragm. Bot. 3: 97-107.

Fekete, G. (1964a): A Bakony növénytakarója (Die Pflanzendecke des Bakony-Gebirges). A Bakony természettudományi kutatásának eredményei I. (Resultationes investigationis rerum naturalinum Montium Bakony I.) - Bakonyi Múzeum, Veszprém, 53 pp.

FeKete, G. (1964b): Botanika és erdőtipológia. - Term.tud. Közl. 95(10): 469-473.

Fekete, G. (1965): Die Waldvegetation im Gödöllöer Hügelland. - Akadémiai Kiadó, Budapest, 223 pp.

Fekete, G. (1966): Der xerotherme Flaumeichen-Buschwald des nördlichen Bakony-Gebirges. Annls hist.-nat. Mus. natn. Hung. 58: 207-221.

Fekete, G. (1967): Der Walnuss-Baumhasel-Felswald der Berge von Oltenien. - Annls hist.-nat. Mus. natn. Hung. 59: 163-173.

FeKete, G. (1973): A CO 2 -koncentráció napi menetei tölgyesek légterében. (The daily changes of $\mathrm{CO}_{2}$ concentration in the air of oak-forests). - Bot. Közlem. 60(1): 43-48.

Fenete, G. (1974a): Átültetési kísérletek Polygonatum odoratum ökotípusokkal különböző fénykörnyezetekben I. A fény-fotoszintézis görbék módosulása. (Umpflanzungversuche mit Polygonatum odoratum Ökotypen bei verschiedenen Lichtverhältnissen I. Modifizierung der Licht-Photosynthesekurven). - Bot. Közlem. 61(3): 199-204.

FEKETE, G. (1974b): Tölgyesek relatív megvilágítása és a gyepszint fajainak eloszlása. (Relative light intensity and distribution of herb layer species in oakwoods). - Studia bot. hung. 9: 87-96.

FEKETE, G. (1974c): Interspecifikus kapcsolatok, kölcsönhatások és az ökológiai niche elemzése tölgyerdei fajokon. (Interspecific connections, correlations and the analysis of the ecological niche in oakwood species). - manuscript, Doctor of the Hungarian Academy of Sciences thesis, Budapest, $282 \mathrm{pp}$.

Fekete, G. (1975a): Aerial environment and tolerance of Polygonatum odoratum (Mill.) Druce in natural communities. - Acta Agron. Acad. Sci. Hung. 24: 89-97.

Fekete, G. (1975b): Átültetési kísérletek Polygonatum odoratum ökotípusokkal különböző fénykörnyezetekben II. A növekedési paraméterek módosulása. (Umpflanzungversuche mit Polygonatum odoratum Ökotypen bei verschiedenen Lichtverhältnissen II. Modifizierung der Wachstumsparameter). - Bot. Közlem. 62(1): 29-31.

FEKETE, G. (1975c): Interspecifikus kapcsolatok, kölcsönhatások és az ökológiai niche elemzése tölgyerdei fajokon. (Interspecific connections, correlations and the analysis of the ecological niche in oakwood species). - manuscript, Hungarian Academy of Sciences, Budapest, 14 pp.

FeKete, G. (2002): Visszapillantás. [Flashback]. - In: BAUER, N. and KenYeres, Z. (eds): 40 éves „A Bakony természeti képe" kutatási program. Tények, képek, emlékek. - Bakonyi Természettudományi Múzeum, Zirc, pp. 149-153.

FEKETE, G. and JA KUCS, P. (1958): Összehasonlító növényföldrajzi tanulmányúton Jugoszláviában. [Comparative plant geographic research tour in Jugoslavia]. - Földr. Közlem. 82(3): 286-292.

FeKete, G. and JAKUCs, P. (1968): A Bükk hegység xerotherm tölgyerdője (Corno-Quercetum). Der xerotherme Eichenwald des Bükk-Gebirges (Corno-Quercetum). - Bot. Közlem. 55: 59-66.

Fekete, G. and Járai-Komlódi, M. (1962): Die Schuttabhangwälder der Gerecse und BakonyGebirge. - Ann. Univ. Sci. Budapest. Rolando Eötvös nom. Sect. Biol. 5: 115-129.

Fekete, G. and Kováts, D. (1974): Magyar herbáriumok 12. A 100 éves Növénytár herbáriumainak története. II. Herbarium Carpato-Pannonicum. Geschichte der Herbarien der 100-jährigen Botanischen Abteilung des Museums II. - Bot. Közlem. 61(1-4): 223-228.

Fekete, G. and Szöcs, Z. (1974): Studies on interspecific association processes in space. - Acta Bot. Acad. Sci. Hung. 20: 227-241.

Fekete, G. and Zólyomi, B. (1966): Über die Vegetationszonen und pflanzengeographischen Charakteristik des Bakony-Gebirges. - Annls hist.-nat. Mus. natn. Hung. 58: 197-205. 
HorÁnszky, A. (1996): Emlékezés liptószentandrási br. Andreánszky Gáborra, születésének századik évfordulóján. (Remembrance of baron Gábor Andreánszky on the occasion of the centenary of his birth). - In: HABLy, L. (ed.): Emlékkötet Andreánszky Gábor (1895-1967) születésének 100. évfordulója alkalmából rendezett emlékülés előadásainak anyagából. Studia Naturalia, vol. 9, pp. 13-20.

JA KUCs, P. (1956): Magyar növénytani kiállitás. (Ungarische botanische Ausstellung). - Népművelési Minisztérium Múzeumi Főosztálya, Budapest, 30 pp.

JA KUCs, P. (1961): Die phytozönologischen Verhältnisse der Flaumeichen-Buschwälder Südostmitteleuropas. - Akadémiai Kiadó, Budapest, 314 pp.

Jakucs, P. (2000): Fekete Gábor 70 éves. [Gábor Fekete 70-year old]. - In: VirÁGH, K. and Kun, A. (eds): Vegetáció és dinamizmus. A 70 éves Fekete Gábort köszöntik tanítványai, barátai és munkatársai. [Vegetation and dynamism. 70-year old Gábor Fekete is greeted by his disciples, friends and colleagues]. MTA ÖBKI, Vácrátót, pp. 13.

JAkucs, P. and Fekete, G. (1957): Der Karstbuschwald des Nordöstlichen Ungarischen Mittelgebirges (Quercus pubescens-Prunus mahaleb nova ass.). - Acta Bot. Acad. Sci. Hung. 3: 253-259.

Jakucs, P., Fekete, G. and Gergely, J. (1959): Angaben zur Vegetation der Moldau und der Dobrudscha. - Annls hist.-nat. Mus. natn. Hung. 51:211-225.

Pócs, T., Domokos-Nagy, É., Pócs-Gelencsér, I. and Vida, G. (1958): Vegetationstudien im Örség. - Akadémiai Kiadó, Budapest, 124 pp.

Précsényi, I., Fekete, G. and Szujkó-Lacza, J. (1967): Pattern studies in Quercus pubescens wood. - Acta Bot. Acad. Sci. Hung. 13: 277-298.

Soó, R. (1971): Aufzählung der Assoziationen der ungarischen Vegetation nach den neueren zönosystematisch-nomenklatorischen Ergebnissen. - Acta Bot. Acad. Sci. Hung. 17(1-2): 127-179.

Soó, R. (1973): A magyar flóra és vegetáció rendszertani-növényföldrajzi kézikönyve V. (Synopsis systematico-geobotanica florae vegetationisque Hungariae V.) - Akadémiai Kiadó, Budapest, 566 pp.

Szujkó-Lacza, J. and Fekete, G. (1971): The correlation of species and habitat factors in a xerothermic oak forest (Orno-Quercetum) stand. - Feddes Repert. 82(3-4): 263-286. ü https://doi.org/10.1002/fedr.4910820303

\section{ARCHIVE SOURCES AND SCIENCE HISTORY DOCUMENTS IN HNHM}

1/1958 Összefoglaló jelentés a Természettudományi Múzeum Növénytára 1957. évben végzett munkájáról. [Compositive report about the work of Department of Botany of Hungarian Natural History Museum in 1957].

67/1958 Összefoglaló jelentés a Természettudományi Múzeum Növénytára 1958. évben végzett munkájáról. [Compositive report about the work of Department of Botany of Hungarian Natural History Museum in 1958].

87/1959 Szöveges beszámoló jelentés a Természettudományi Múzeum Növénytára 1959. évi munkájáról. [Compositive report about the work of Department of Botany of Hungarian Natural History Museum in 1959].

35/1960 Az 1960. évi akadémiai céltámogatás témánkénti bontása. [Academic assistances per topics in 1960].

38/960 „Takarékossági feladatterv” Zólyomi Bálint, a Növénytár vezetőjének levele, Budapest, 1960.04.21. ["Frugality plan" - letter of Bálint Zólyomi, head of the Department of Botany, Budapest, 21.04.1960].

68/1961 Jelentés a TTM Növénytár külföldi kapcsolatainak 1945 óta történt fejlődéséről. [Report about the development of international contacts of Department of Botany of Hungarian Natural History Museum till 1945].

57/1961 külföldi tanulmányút kérelmek. [Application for external studies]. 
181/1961-N Kérelem. [Application]. (Pócs T., Budapest, 1961.12.28.)

179/1961-N Nyilatkozat. [Declaration]. (Jakucs P., Budapest, 1961.12.23.)

6/1962-N A Természettudományi Múzeum Növénytára 1961. évi összesített munkajelentése. [Compositive report about the work of Department of Botany of Hungarian Natural History Museum in 1961]. (Zólyomi B., Budapest, 1962.01.06.)

82/1962-N Jelentés a nemzetközi kapcsolatokról. [Report about international contacts]. (Zólyomi B., Budapest, 1962.04.26.)

86/1962-N Válaszlevél Éri István, a Bakonyi Múzeum főigazgatója részére. [Response to István Éri, director-general of the Museum of Bakony Mts]. (Zólyomi B., Budapest, 1962.05.02.)

98/1962-N Tanulmányút kérelem a Szovjetúnióba. [Application for studies in Soviet Union]. (Fekete G., Budapest, 1962.06.15.)

110/1962-N Külföldi kulturális programtervezet felterjesztése. [Petition of an external cultural draft programme]. (Zólyomi B. 1962.06.20.)

220/1963-N Lektori vélemény. A Keszthelyi Balaton Múzeum természettudományi kiállításának forgatókönyvéről (botanika). [Review for scenario of the natural science exhibition of Balaton Museum in Keszthely (botany)]. (Fekete G., Budapest, 1963.11.18.)

27/1963-N Kérvény, az MTA Tudományos Minősítő Bizottságának, önálló belföldi aspirantúra érdekében. [Application to the Scientific Qualification Committee of Hungarian Academy of Sciences for individual internal aspiration]. (Fekete G. Budapest, 1963.01.15.)

227/1963-N Felterjesztés a Tudományos Minősítő Bizottság részére. Dr. Fekete Gábor „Erdővegetáció-tanulmányok a Gödöllői-dombvidéken. A hűvöskontinentális erdőssztyep erdőinek összehasonlító növényföldrajzi vizsgálata” c. kandidátusi disszertáció témájában. [Petition to the Scientific Qualification Committee in the topic of candidate dissertation entitled "Studies on forest vegetation in the Gödöllö Hills. Comparative plant geographical analyses of coldcontinental forest steppe forests“ by Dr Gábor Fekete]. (Zólyomi B. Budapest, 1963.11.14.)

66/1965-N/2 (Bizalmas) Felterjesztés Székessy Vilmos föigazgató felé, hogy Jakucs Pál tölthesse be a Növénytár megüresedett osztályvezetőhelyettesi pozícióját. [(Confidential) Petition to Vilmos Székessy, director-general asking appointment of Pál Jakucs for assistant head of department]. (Zólyomi B. Budapest, 1965.06.01.)

66/1965-N/3 (Bizalmas) Felterjesztés Székessy Vilmos főigazgató felé, hogy Fekete Gábor tölthesse be a Jakucs megüresedett státushelyét. [(Confidential) Petition to Vilmos Székessy, directorgeneral asking appointment of Gábor Fekete for assistant head of department]. (Zólyomi B. Budapest, 1965.06.01.)

1966/201-N Jegyzőkönyv a TTM Növénytára vezetésének átadásáról, illetve átvételéről. [Protocol of conveyance-receipt of leadership of Department of Botany of Hungarian Natural History Museum]. (Bélley Pálné, Budapest, 1966.05.30.)

72/1957-Nt Jelentés az 1957. dec. 27-én Esztergomban végzett herbárium-szemrevételező munkámról. [Report about my herbarium work in Esztergom on 27 December of 1957]. (Fekete G. Budapest, 1958.01.03.)

Documents without scores: Final research plan of Department of Botany for 1954 (Zólyomi B. Budapest, 1953.08.25.); account about Museum references of the academic works in 1954; Annual plans and reports (1953-1977) of Department of Botany; Annual plans and reports (1954-1977) of Gábor Fekete; Documents, manuscripts, reviews of fond of Gábor Fekete in the History of Science Collection; handwritten field diaries of Gábor Fekete had been given to the Hungarian Natural History Museum by the author: Bakony Region 1959-1960, Bakony Region 1960-1962; Bakony Region 1963; Gödöllő Hills 1960, R. P. Rumina 1960, Romania, Bulgaria 1961; Bulgaria II., Soviet Union 1967, Soviet Union 1971, Bulgaria 1973.

(submitted: 30.08.2017, accepted: 09.11.2017) 